\title{
Biology and Control of Coast Cockspur in Sugarcane ${ }^{1}$
}

\author{
Dennis Calvin Odero, Ron Rice, and Les Baucum²
}

Coast cockspur (Echinochloa walteri) is a relative of barnyardgrass that is native to North America (Tiner 1993). It is also referred to as Walter's millet and is widely distributed throughout the eastern United States from Massachusetts inland to Minnesota and south to Florida and Texas (USDA-NRCS 2012). Coast cockspur is widespread throughout Florida and is commonly found in moist to wet cultivated fields, marshes, and swamps, as well as along canals, ditch banks, and the edges of water bodies (CAIP 2012). In South Florida, coast cockspur typically begins to infest sugarcane during the onset of rainfall in late spring.

\section{Biology and Life Cycle}

Coast cockspur is an erect annual grass that can grow up to 6 feet tall (Figure 1). Seedling leaves are rolled in a bud and have no ligule. Leaf blades are flat, linear, and smooth to sandpapery. The leaf blades typically grow approximately 3/4-1 inch wide and up to 24 inches long. Like barnyardgrass, coast cockspur has no ligule (Figure 2). Leaf sheaths are covered with very dense stiff hairs that can prick the skin (Figure 3). The stem is thick and somewhat flattened. The inflorescence is a conspicuous, erect bristle head. It is somewhat branched, open, and made up of many 3-12inch spikelets (Figure 4). Seeds are on the lower side of the branches and are bristly with long stiff hair at the tip. Coast cockspur propagates by seed. It is highly productive and an abundant seed source for migratory birds.

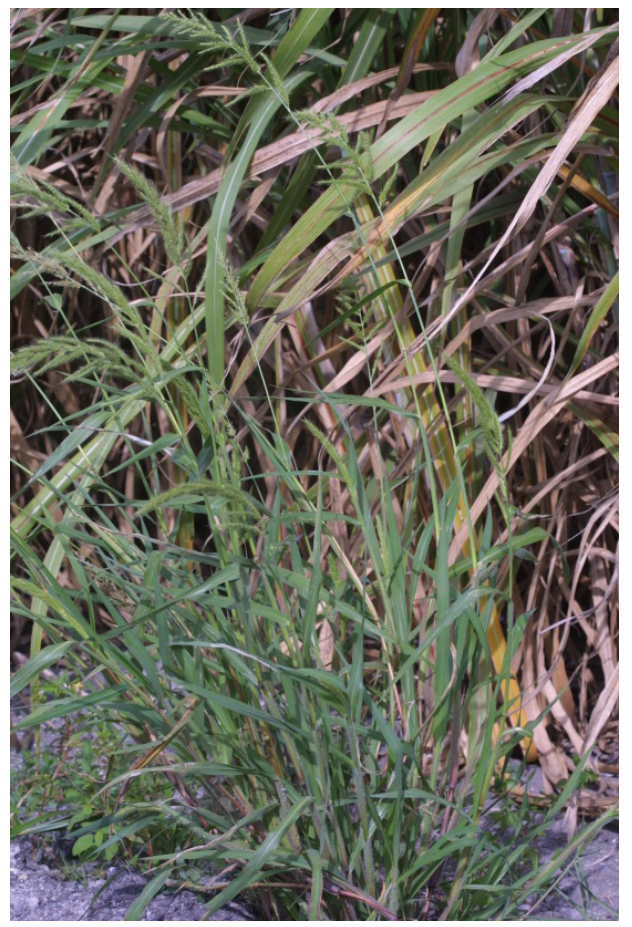

Figure 1. Coast cockspur.

Credits: D. C. Odero

1. This document is SS-AGR-366, one of a series of the Agronomy Department, Florida Cooperative Extension Service, Institute of Food and Agricultural Sciences, University of Florida. This publication is a part of the Florida Sugarcane Handbook. For more information, contact the editor of the Sugarcane Handbook, Ronald W. Rice (rwr@ufl.edu). Original publication date January 2013. Please visit the EDIS website at http://edis.ifas.ufl.edu.

2. Dennis Calvin Odero, assistant professor, Agronomy Department, Everglades Research and Education Center, Belle Glade, FL; Ron Rice, Extension agent, Palm Beach County, Belle Glade, FL; and Les Baucum, Extension agent, Hendry County, LaBelle, FL; Florida Cooperative Extension Service, Institute of Food and Agricultural Sciences, University of Florida, Gainesville, FL 32611.

The use of trade names in this publication is solely for the purpose of providing specific information. UF/IFAS does not guarantee or warranty the products named, and references to them in this publication do not signify our approval to the exclusion of other products of suitable composition. All herbicides should be used in accordance with directions on the manufacturer's label.

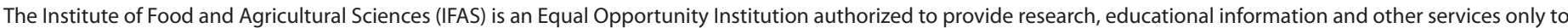

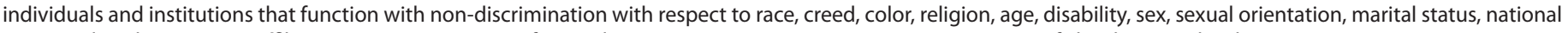
origin, political opinions or affiliations. U.S. Department of Agriculture, Cooperative Extension Service, University of Florida, IFAS, Florida A\&M University Cooperative Extension Program, and Boards of County Commissioners Cooperating. Nick T. Place, Dean 


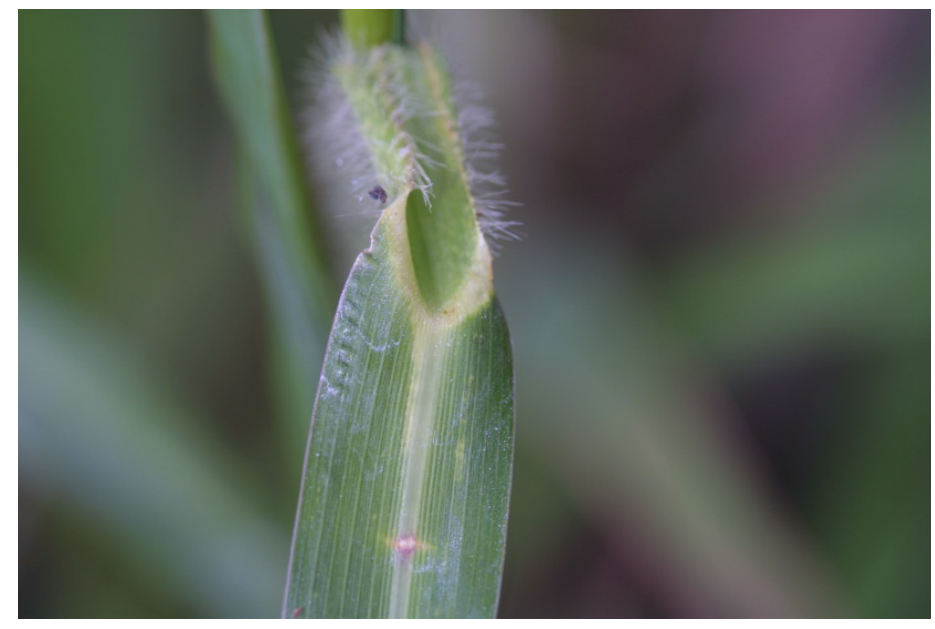

Figure 2. Coast cockspur leaf with no ligule.

Credits: D. C. Odero

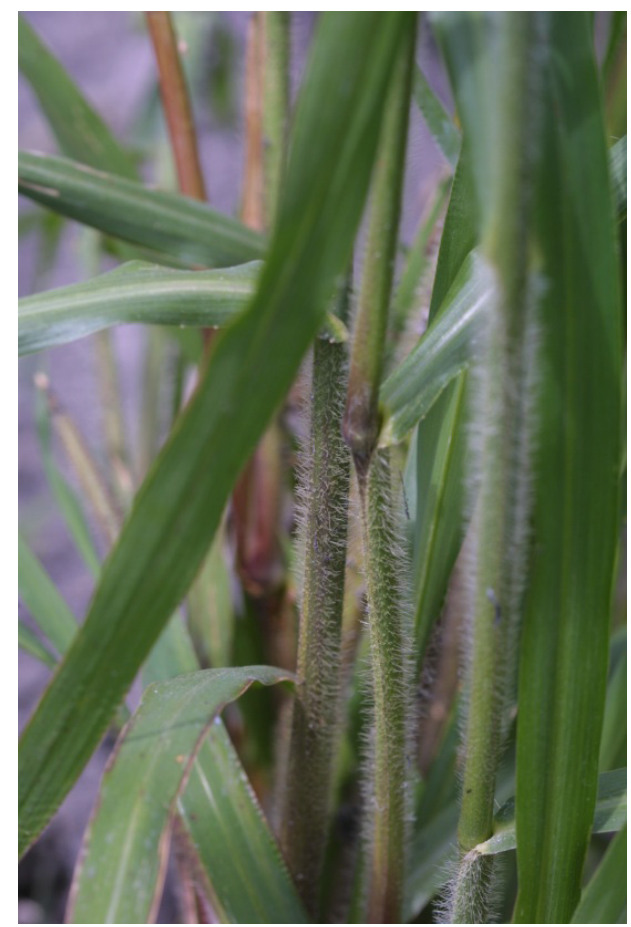

Figure 3. Coast cockspur leaf sheaths covered by dense stiff hairs. Credits: D. C. Odero

\section{Control}

Currently, no herbicides are labeled for selective control of coast cockspur in sugarcane. The best control options are tillage between the row middles, crop rotation, or spot treatments with glyphosate. Glyphosate at a $2 \%$ solution is effective on seedling and mature coast cockspur. Control with glyphosate can be improved by adding ammonium sulfate to the spray solution, especially for glyphosate formulations not loaded with adjuvants.

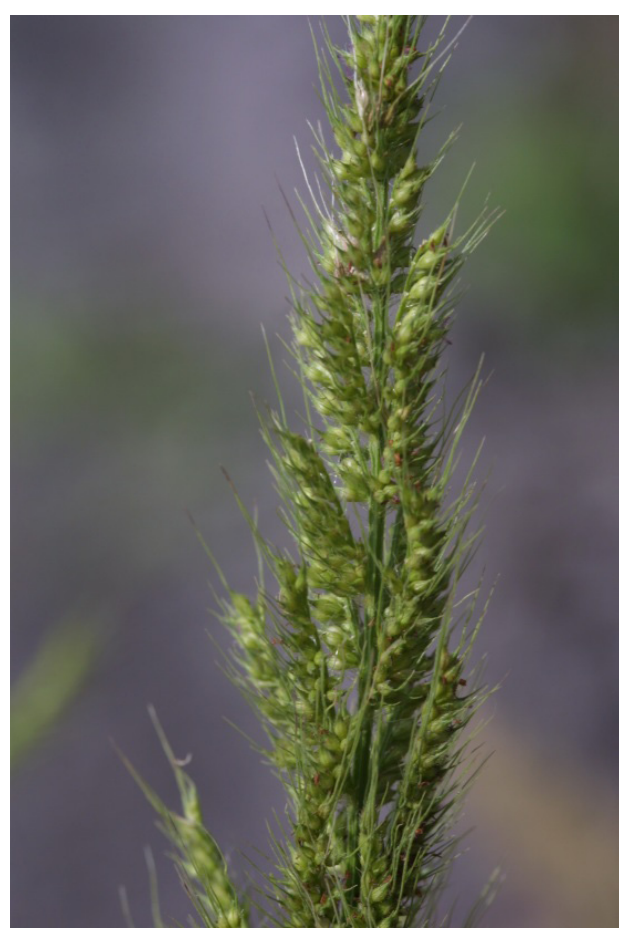

Figure 4. Coast cockspur inflorescence.

Credits: D. C. Odero

\section{References}

Center for Aquatic and Invasive Plants (CAIP), University of Florida Institute of Food and Agricultural Sciences.

"Walter's Millet, Coast Cockspur." Accessed November 5, 2012. http://plants.ifas.ufl.edu/node/137.

Tiner, R. W. 1993. Field Guide to Coastal Wetland Plants of the Southeastern United States. Amherst: University of Massachusetts.

United States Department of Agriculture, Natural Resources Conservation Service (USDA-NRCS). "(Pursh) A. Heller Coast Cockspur Grass.” Accessed November 5, 2012. http://plants.usda.gov/java/profile?symbol=ECWA. 